\title{
Factors Affecting Farmers' Perception toward Agricultural Land Sustainability in Peri-Urban Areas of Pekalongan City
}

\author{
Imade Yoga Prasada* and Masyhuri \\ Department of Agricultural Socio-Economics, Faculty of Agriculture, Universitas Gadjah Mada, \\ Yogyakarta, Indonesia \\ ${ }^{*}$ Corresponding author: imade.yogap@gmail.com
}

\begin{abstract}
Over the past few decades, agricultural land sustainability on the peri-urban areas face a threat to the agricultural land conversion, especially on the peri-urban areas of Pekalongan City. The sustainability of agricultural land is determined by the level of farmers' perception. Therefore, this research was conducted to determine the factors that influence farmers' perceptions toward agricultural land sustainability in peri-urban areas of Pekalongan City. The peri-urban areas of Pekalongan City were selected by purposive sampling method with a total sample of 90 farm owners and cultivators. Data were analyzed using OLS (Ordinary Least Square) regression model. The results have shown that the factors influencing farmers' perceptions toward agricultural land sustainability in the peri-urban area of Pekalongan City were farmers' knowledge, farmers' land tenure and access to information. Based on the results of the study, the variables of farmers' knowledge and land tenure had a negative impact, while the access to agricultural information had a positive impact on farmers' perceptions. These results have the implication for farmers, that their perceptions can be improved by making advances to the quality of agricultural land in the suburbs, reducing both production and price risks and increasing the intensity of counseling or training related to agricultural activities in the suburbs of Pekalongan City.
\end{abstract}

Keywords: agricultural land sustainability; farmers' perception; Pekalongan City; peri-urban areas

Cite this as: Prasada, I. Y., \& Masyhuri. (2020). Factors Affecting Farmers' Perception toward Agricultural Land Sustainability in Peri-Urban Areas of Pekalongan City. Caraka Tani: Journal of Sustainable Agriculture, 35(2), 203-212. doi: http://dx.doi.org/10.20961/carakatani.v35i2.31918

\section{INTRODUCTION}

Agricultural land essentially has many strategic economic, social and ecological roles. Socially and economically, agricultural land is the land that is able to produce and meet the food needs of the population (Didomenica and Gordon, 2016; Rezai et al., 2016). In addition, the strategic role of agricultural land is closely related to the environmental aspects or ecological aspects. In terms of ecological aspect, the strategic role of agricultural land is the function of agricultural land as a buffer zone of pollution caused by economic activities in the city center, an organic waste decomposer, a groundwater filter medium, a flood control zone and a supporting zone for sustainability of wetland ecosystem (Jamal and Mortez, 2014; Ramzi et al., 2017). The three strategic roles of agricultural land are interrelated with each other. Therefore, the sustainability of agricultural land can be seen from three dimensions of sustainability, namely the economic, social and ecological dimensions (Sulewski et al., 2018).

Ecological conditions of agricultural land will support the increase in farm production. This will improve the economic value of agricultural land and increase participation, as well as

\footnotetext{
* Received for publication July 9, 2019

Accepted after corrections May 23, 2020
} 
farmer satisfaction from the social dimension (Hasanshahi et al., 2015). However, over the past few years, the existence of agricultural land faces a major menace to the massive and consistent conversion of agricultural land, especially the land in the peri-urban area, without the exception of agricultural land in peri-urban of Pekalongan City. Data from the Central Statistics Agency in the period of 2011-2015, Indonesia experienced an average conversion of agricultural land by $0.11 \%$ per year. The average was far lower than the average conversion of agricultural land that occurred in urban areas in the City of Pekalongan which reached $1.81 \%$ (BPS-Statistics of Pekalongan Municipality, 2018).

Pekalongan City experienced consistent agricultural land conversion from 1989 to 2017 with a decrease in agricultural land area of $44.16 \%$ during the period (BPS-Statistics of Pekalongan Municipality, 2018). The agricultural land conversion in the city area will spread to periurban areas. This is known as the phenomenon of urban expansion or urban sprawl (Sudirman, 2012). Urban sprawl will subsequently trigger the trade-offs on agricultural land use, causing the rent of land use to be higher (Daulay et al., 2016; Sumarga and Hein, 2016). The phenomenon of urban sprawl will increasingly impact on the existence of agricultural land along with the increase in population and the increase in variation of population needs (Jiang and Zhang, 2016; Yasar and Siwar, 2016).

Various factors can influence agricultural land conversion in the peri-urban areas. One of these factors is the positive or negative views or perceptions of farmers toward the agricultural land sustainability in the peri-urban areas that they own and manage. The higher the farmer's perception toward the sustainability of agricultural land in peri-urban areas, the higher the level of sustainability of the agricultural land. Conversely, the lower the farmer's perception of the agricultural land sustainability in peri-urban areas, the lower the level of sustainability of agricultural land.

Perception can be interpreted as a process of someone's activity in receiving information through the senses and then giving the impression, judgment, opinion, feeling and interpreting something based on the information presented from the source (Kawung et al., 2016). Perception includes objects around humans that are captured through sensory devices and projected on certain parts of the brain so that the humans can observe the objects (Duwit et al., 2015). Perception begins when a person receives a stimulus from the outside that is captured by one's assisting organs and then enters the brain, in which a process of thinking takes place, which ultimately manifests in an understanding (Aulifia et al., 2016). Perception is a cognitive process that allows one to interpret and understand the surrounding environment. Therefore, perception becomes a very important thing that will be experienced by someone when getting a particular stimulus from the surrounding environment. The stimulus can be in the form of various changes that occur in the surrounding environment or other social phenomena that are accepted by a person. Perception allows a person to act according to the stimulus he or she receives (Faridhavin et al., 2016).

Research related to farmers' perceptions of the sustainability of agricultural land needs to be improved in order to increase the sustainability of agricultural land in the suburbs of Pekalongan City. The farmers' perception of the sustainability of agricultural land in the suburbs of Pekalongan City will determine the behavior of farmers to maintain the sustainability of agricultural land (Creemers et al., 2019). The increasingly high level of farmers' perceptions of the sustainability of agricultural land will encourage farmers to more easily adopt new technologies that can improve the sustainability of their farming activities (Kiełbasa et al., 2018).

A research in Brazil has reported that the higher level of farmers' perceptions influences their decisions to continue maintaining the sustainability of the farms they manage (da Motta and Ortiz, 2018). A study conducted in Bali Province related to farmers' perceptions of sustainable agricultural food land protection policies using the Ordinary Least Square (OLS) method has shown that the factors that influence farmers' perceptions of policies on sustainable food agricultural land protection are farming culture, attitudes toward change, self-confidence, courage risk, level of intelligence, rationality, cooperation, role in farmer groups and the intensity of counseling or socialization related to Sustainable Food Agricultural Land Protection (Perlindungan Lahan Pertanian Pangan Berkelanjutan/PLP2B) (Suharyanto et al., 2017).

In addition, research in Bogor City/Regency area with a correlation test has highlighted that 
farmers' perceptions of government support in implementing sustainable agricultural systems are closely related to the level of formal education and land tenure (Virianita et al., 2019). Higher levels of farmers' education and land tenure have a strong relationship in improving farmers' perceptions. A research in Brazil, using a binary probit regression model, has concluded that farmers' decision to receive environmental services payment is influenced by farmers' perceptions of their environmental conditions (da Motta and Ortiz, 2018).

A research in the Jogja Hydroponic Community confirms that perceptions of hydroponic development are influenced by activeness, experience and the role of admin (Aulifia et al., 2016). In addition, a research related to companions' perceptions of the implementation of the UPSUS PAJALE (special effort for increasing production of rice, maize and soybean) Program in the Special Region of Yogyakarta has exemplified that perceptions can be influenced by the knowledge. The higher knowledge has a positive impact on the increase in perceptions (Faridhavin et al., 2016). The research confirms that the higher level of perception shows increasingly positive perception.

A study in Pakistan shows that farmers have negative perceptions of agricultural insurance programs and with the probit model typifies that education factors and previous credit programs influence farmers' perceptions related to agricultural insurance programs (Ghazanfar et al., 2015). Another study in Ethiopia using the probit regression model concludes that farmers' perceptions of climate change are influenced by location, gender, age, education, soil fertility status, climate change information and access to credit services (Habtemariam et al., 2016).

Previous studies did not discuss the factors that influence farmers' perceptions toward the agricultural land sustainability in the peri-urban areas. This aspect, however, is very important to scrutinize because agricultural land on the periurban areas is vulnerable to the conversion of agricultural land. Therefore, this research was carried out to fill the gap among the previous studies, to determine the factors that influence farmers' perceptions of the agricultural land sustainability in the peri-urban areas of Pekalongan City, Central Java.

\section{MATERIALS AND METHOD}

This research was conducted in the suburbs of Pekalongan City. Pekalongan suburbs were determined as research locations using the purposive sampling technique because Pekalongan City had experienced massive and consistent conversions of agricultural land for several decades. Pekalongan City experienced a conversion of agricultural land by $55.84 \%$ during the period of 1989-2017 (BPS-Statistics of Pekalongan Municipality, 2018). Therefore, the conversion of agricultural land occurring in urban areas was very potential to spread-out to suburban areas due to the expansion of urban areas (Ustaoglu and Williams, 2017). The suburban area is an area located between two regions with different environmental conditions, namely between an area with an urban appearance and an area with a rural appearance (Fauzan et al., 2017; Sari and Santoso, 2017). Therefore, the suburbs of the city in this study are areas that are outside the Pekalongan City area, but are directly adjacent to Pekalongan City. The Pekalongan suburbs cover four sub-districts, namely Batang and Warungasem, which are the administrative areas of Batang Regency, and Buaran and Tirto, which are the administrative areas of Pekalongan Regency.

The number of respondents in this study was determined using the Slovin method with the following formula (Haryanto et al., 2018):

Where:

$$
n=\frac{N}{1+N e^{2}}
$$

$$
\begin{array}{ll}
\mathrm{n} & =\text { Number of samples; } \\
\mathrm{N} & =\text { Total population; } \\
\mathrm{e} & =\text { Margin of error }
\end{array}
$$

The total population of farmers in the suburbs of Pekalongan City is 849 farmers. The margin of error was set at $10 \%$. Therefore, the respondents of this study were 90 farmers, who were divided proportionally in each location of study (24 respondents from Batang Sub-district, 21 respondents from Warungasem Sub-district, 14 respondents from Buaran Sub-district and 31 respondents from Tirto Sub-district). The respondents were selected using the simple random sampling method. The data retrieval was conducted by interview using a questionnaire carried out in May-June 2019. 
The method used to determine the factors influencing farmers' perceptions of the sustainability of agricultural land in the periurban areas of Pekalongan City was the OLS model. The factors include farmers' knowledge, farmer education, land tenure and access to agricultural information. The variables of farmers' perceptions of the sustainability of agricultural land in the peri-urban areas of Pekalongan City cover the process of filtering, organizing, interpreting various forms of information about the sustainability of agricultural land in the suburbs. The higher level of farmers' perception shows that farmers' perception is increasingly positive towards the sustainability of agricultural land in the suburbs of Pekalongan City. Farmers' knowledge about agricultural activities is all the insights that have been held by respondents about agriculture, which are sourced from formal education, experience, internet, environment, mass media, radio, etc. In this study, the farmers' knowledge was measured using a Likert scale. The variable of farmers' education was the last level of formal education taken by respondents until the research activities were carried out and measured in units of years. The land tenure is the area of agricultural land owned and managed by farmers and measured in hectares. The access to agricultural information is the level of ease of farmers in finding agricultural information and this variable was measured using a Likert scale. The regression model used in this study can be written as follows:

$$
\mathrm{LN}(\text { Perception })=\alpha 0+\alpha 1 \mathrm{LN}(\text { Knowledge })+\alpha 2 \mathrm{LN}(\text { Educ })+\alpha 3 \mathrm{LN}(\mathrm{LT})+\alpha 4 \mathrm{LN}(\mathrm{AAI})
$$

Expected sign of the estimation: $\alpha 1, \alpha 2, \alpha 3, \alpha 4>0$

Where:

$\begin{array}{ll}\text { Perception } & =\text { Farmers' perception }(\%) \\ \text { Knowledge } & =\text { Farmers' knowledge about agriculture activity }(\%) \\ \text { Educ } & =\text { Farmers' education (years) } \\ \text { LT } & =\text { Land tenure (ha) } \\ \text { AAI } & =\text { Farmers' access to agricultural information }(\%)\end{array}$

Regression analysis can be done if it meets the classical assumptions, so that the best model which has the BLUE characteristic (Best Linier Unbiased Estimator) can be obtained. Testing this classic assumption includes testing for normality, multicollinearity and heteroscedasticity. The normality was examined using the JarqueBera test by comparing the value of Jarque-Bera statistic to chi-squared table. Residuals are said to be normally distributed if the Jarque-Bera statistic is greater than chi-squared table. Normality test is a test in the research data to find out whether the type of data collected in the field is in accordance with the theoretical distribution (normal distribution). A good regression model is to have a residual value that is normally distributed. The multicollinearity test was done by using a correlation test between the independent variables in the model. This multicollinearity assumption is fulfilled when the correlation coefficient between the independent variables is less than 0.80. Multicollinearity test was conducted to test whether the regression analysis model found an influence between independent variables. A good regression model is a regression model in which there is no correlation between independent variables. The heteroscedasticity test was carried out using the White test. If the value of Obs* R-squared does not exceed the critical chi-square value $\left(\mathrm{X}^{2}\right)$ at the chosen level of significance, then the regression model is homoscedasticity. The heteroscedasticity test was conducted in this study with the aim to find out whether in the regression model variance and residual inequalities occured in one observation to another observation. A good regression model is homoscedasticity, that is, variants and residuals, one observation to another is fixed (Gujarati, 2004).

\section{RESULTS AND DISCUSSION}

\section{Normality test}

Tests were carried out using the Jarque-Bera Test analysis method. The results of normality testing in the regression model used can be seen in Figure 1. 


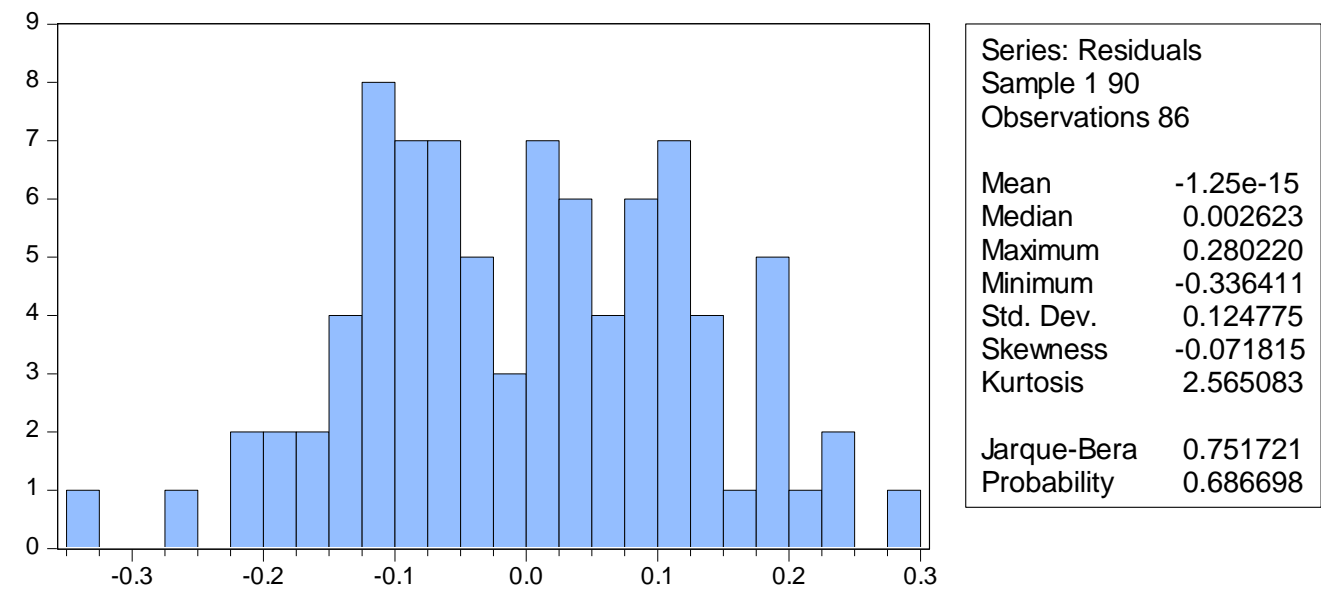

Figure 1. Jarque-Bera test results of farmers' perception model

Figure 1 demonstrates that the Jarque-Bera Probability value was 0.687 . The value was greater than the value of $\alpha=1 \%$, so that $\mathrm{H}_{0}$ stating a normally distributed residual failed to be rejected. This denotes that the residual regression model used to determine the factors that influence farmers' perceptions toward the agricultural land sustainability in peri-urban areas of Pekalongan City have normal distribution.

\section{Multicollinearity test}

The multicollinearity test results of the regression model used in this study are presented in Table 1 .

Table 1. Multicollinearity test results of farmers' perception model

\begin{tabular}{lcccc}
\hline & Knowledge & Educ & LT & AAI \\
\hline Knowledge & 1.000000 & 0.233345 & 0.011595 & 0.340714 \\
Educ & 0.233345 & 1.000000 & 0.221496 & 0.211470 \\
LT & 0.011595 & 0.221496 & 1.000000 & 0.034173 \\
AAI & 0.340714 & 0.211470 & 0.034173 & 1.000000 \\
\hline
\end{tabular}

Table 1 summarizes that all independent variables in the regression model of farmers' perceptions of the sustainability of agricultural land in the peri-urban areas of Pekalongan City had a correlation coefficient value that was smaller than 0.80 . This indicates that the analyzed model does not have a multicollinearity problem because there is no strong correlation between the independent variables.

\section{Heteroscedasticity test}

The results of heteroscedasticity testing on the regression model of farmers' perceptions of the sustainability of agricultural land in the peri-urban areas of Pekalongan City are demonstrated in Table 2 .

Table 2. Heteroscedasticity test results of farmers' perception model

\begin{tabular}{llll}
\hline F-statistic & 1.549915 & Prob. F (14.71) & 0.1160 \\
Obs*R-squared & 20.13076 & Prob. Chi-Square (14) & 0.1261 \\
Scaled explained SS & 13.97464 & Prob. Chi-Square (14) & 0.4516 \\
\hline
\end{tabular}

Table 2 shows that the probability value of Obs*R-squared was 0.126 . The probability value of Obs*R-squared was greater than $\alpha=1 \%$ so that $\mathrm{H}_{0}$ stating the variance of a constant-value error term failed to be rejected. This confirms that the model tested does not have a heteroscedasticity problem or the model has homoscedastic characteristic.
Factors affecting farmers' perceptions of the agricultural land sustainability in peri-urban of Pekalongan City

Multiple linear regression analysis is an analysis conducted to determine the causal relationship between independent variables on the dependent variable. The analysis in this study was used to determine the factors influencing the high 
and low perceptions of the farmers on the sustainability of agricultural land in the peri-urban areas of Pekalongan City. The independent variables tested in this study were the knowledge of farmers related to agricultural activities they manage variable (\%), farmers' education level (year), farmers' land tenure (ha) and farmers' access to agricultural information (\%), while the dependent variable was farmers' perception of the sustainability of agricultural land in the peri-urban of Pekalongan City variable, expressed in percent. The results of multiple linear regression analysis of farmers' perceptions toward agricultural land sustainability in the peri-urban areas of Pekalongan City can be seen in Table 3 .

Table 3. Factors affecting farmers' perceptions of the agricultural land sustainability in peri-urban of Pekalongan City

\begin{tabular}{lcccc}
\hline Independent variables & Expected sign & Coefficient & t-statistic & Prob t-statistic \\
\hline Knowledge & + & $-0.173^{*}$ & -1.922 & 0.058 \\
Educ & + & -0.002 & -0.044 & 0.965 \\
LT & + & $-0.038^{* * *}$ & -2.393 & 0.019 \\
AAI & + & $0.066^{* * *}$ & 2.741 & 0.008 \\
Constanta & $+/-$ & $4.595^{* * *}$ & 12.407 & 0.000 \\
\hline R-squared & & & 0.152 \\
Adjusted R-squared & & & 0.110 \\
F statistic & & & 3.630 \\
Prob (F statistic) & & & 0.009 \\
\hline Note: ${ }^{* * * *}$ significant at the error rate of $\%(\alpha=0.01){ }^{* *}$ significant at the error rate of $5 \%(\alpha=0.05) ;{ }^{*}$ significant at \\
$\quad$ the error rate of $10 \%(\alpha=0.10)$
\end{tabular}

Table 3 exhibits that the $\mathrm{F}$ value of statistics in the regression model used was 3.630. This value had a statistical $\mathrm{F}$ probability of 0.009 . F statistical probability value of 0.009 was smaller than $\alpha=$ $1 \%$, meaning that $\mathrm{H}_{0}$ showing no effect of independent variables on the dependent variable simultaneously was rejected. These results indicate that the independent variables in the model used in this study have a simultaneous influence on the dependent variable, namely farmers' perceptions of the sustainability of agricultural land in the peri-urban areas of Pekalongan City.

Table 3 also shows the adjusted R-squared value of the model used at 0.110 . This value means that by $11.00 \%$, the variation of the farmer perception variable on the sustainability of agricultural land in the peri-urban areas of Pekalongan City can be explained by the independent variables contained in the regression model, while the remaining $89.00 \%$ is matched by other variables outside the research model. The adjusted R-squared value was quite low. This shows that there are still other variables outside the model that affect the level of farmers' perceptions of the sustainability of agricultural land in the suburbs of Pekalongan City. Other variables outside this research model that might influence farmers' perceptions toward the sustainability of agricultural land in the suburbs of Pekalongan City are farm income, risk level of farming, the role of farmer groups in the suburbs (Suharyanto et al., 2017; Virianita et al., 2019).

In Table 3, it can be seen that the constant value having a probability of $0.000<\alpha(0.01)$ indicates that if the independent variable in the model is considered constant or worth zero, then the influence of other variables outside the model on the farmers' perception variable is 4.595 . If other variables outside the model increase by $1 \%$, then the farmers' perception of the agricultural land sustainability in the peri-urban of Pekalongan City will increase by $4.595 \%$. In addition, in the $t$ test, it is known that the variables that have a significant effect on farmers' perceptions include farmers' knowledge, farmers' land tenure and access to agricultural information by farmers.

Table 3 also presents that farmers' knowledge regarding agricultural activities in the peri-urban areas of Pekalongan City had a regression coefficient of -0.173 . The regression coefficient shows a significance value of $t$ (prob t-statistic) of 0.058 . The significance of $\mathrm{t}$ was less than $\alpha 10 \%$, so that $\mathrm{H}_{0}$ expressing no effect of the variable farmers' knowledge regarding agricultural activities to the farmers' perceptions variable was rejected. This shows that the farmers' knowledge variable about agricultural activities has a 
significant effect on farmers' perceptions. However, the regression coefficient of the knowledge variable about agricultural activities is negative, meaning that an increase in farmers' knowledge of agricultural activities will reduce farmers' perceptions of the agricultural land sustainability in the peri-urban areas of Pekalongan City. These results are not in accordance with the expected sign that has a positive value.

A research in the Special Region of Yogyakarta has reported that knowledge has a positive influence on the formation of perception. The higher knowledge will support the formation of positive perceptions (Faridhavin et al., 2016). This discrepancy can be caused by the environmental conditions that do not support agricultural activities in the peri-urban areas of Pekalongan City, so that farmers' knowledge is not in accordance with the farmers' expectations to obtain high production yields.

The agricultural environments in the periurban areas of Pekalongan City mostly have low environmental quality. This is due to excessive use of fertilizers, thus polluting the environment of agricultural land (Pradika et al., 2019). In addition, agricultural land has been intruded by sea water and contaminated by industrial waste (batik and jeans). Sea water intrusion and industrial waste pollution cause agricultural land to be vulnerable to damage and trigger a decrease in production and productivity of cultivated plants (Werner et al., 2013; Delsman et al., 2014). Damage to the quality of agricultural land due to sea water and industrial waste causes soils to become acidic. This damage can be overcome by using superior seeds that are resistant to high salinity, as well as planning and improving the quality of irrigation system (Erfandi and Rachman, 2011; Saturday, 2018).

The variable famers' education (Educ) had an insignificant effect on farmers' perception, with significance value of $t$ bigger than alpha $1 \%, 5 \%$ and $10 \%$. This shows that the level of education does not have a significant influence on the formation of farmers' perceptions toward the sustainability of agricultural land in the suburbs. The average level of education of farmers in the suburbs of Pekalongan City is still very low, ranging between 0 and 6 years. Low education level will hamper the process of delivering information to farmers in the suburbs (Faridhavin et al., 2016).
Table 3 shows that the variable farmers' land tenure had a probability value or significance $t$ value of 0.019 . This value was smaller than the alpha value of $5 \%$ and this means the value of $\mathrm{H}_{0}$, which states no influence from the variable farmers' land tenure to the farmers' perceptions is rejected. These results illustrate that the variable farmers' land tenure has a significant effect on farmers' perceptions. The regression coefficient of land tenure variable was -0.038 , which signifies that any increase in the farmers' land tenure variable can reduce farmers' perceptions toward the agricultural land sustainability in peri-urban areas of Pekalongan City. This result is not in line with the expected sign.

A research in Jember Regency has reported that agricultural land is the most important asset for farmers so that wider land ownership can have a positive impact on the increase in profits derived from farming activities undertaken (Rondhi and Adi, 2018). However, the agricultural land managed by farmers is increasingly widespread and as a consequence, this increases the risk of farmers in carrying out farming activities on the peri-urban areas, both the risk of crop failure due to pests and plant diseases, or due to environmental conditions that are not suitable for growing plants and the risk of selling prices of agricultural products come down during the harvest (Purbiyanti et al., 2017; Prasada et al., 2018).

The risks in farming activities can be overcome by implementing an agricultural insurance program to protect farmers against the risks and uncertainties in the production process due to environmental conditions that do not support the cultivation of crops (Septian and Anugrah, 2014). Risks related to the price of agricultural products can be managed by implementing a floor price program scheme or Government Purchase Price (GPP) scheme that takes sides and benefits to the farmers (Clay et al., 2018).

Table 3 summarizes that farmers' access to agricultural information (AAI) had a significant $t$ value of 0.008 . The significance value of $t$ was smaller than the alpha value of $1 \%$, so that $\mathrm{H}_{0}$, which signifies no influence of farmers' access to agricultural information on farmers' perceptions, was rejected. These results indicate that farmers' access to agricultural information influences the farmers' perceptions. The regression coefficient on agricultural information access was 0.066. 
This coefficient means that any increase in access to agricultural information will lead to an increase in farmers' perceptions of the sustainability of agricultural land in the peri-urban areas of Pekalongan City. Therefore, access to agricultural information for farmers needs to be improved so their perceptions of the agricultural land sustainability on the peri-urban areas can be enriched and the existence of agricultural land can also be sustained. This access to information can be improved by increasing counseling and training for farmers about farming activities that are run in the peri-urban areas of Pekalongan City (Obaniyi et al., 2014).

\section{CONCLUSIONS}

The results of this study have shown that the variables of farmer's knowledge and farmer's land tenure have reversed effects (negative sign) on farmers' perceptions toward agricultural land sustainability in peri-urban areas of Pekalongan City, while access to agricultural information has a direct influence (positive sign) on farmers' perceptions. The improvement of their perceptions toward the agricultural land sustainability in peri-urban areas of Pekalongan City can be made by increasing the quality of agricultural land by making improvement on agricultural irrigation channels, reducing production risk (using salinity-resistant seeds) and price risk (implementing Government Purchase Price) and increasing the access of the farmers to agricultural information.

\section{ACKNOWLEDGEMENT}

The authors acknowledge the Education Fund Management Institute (LPDP / Indonesian Endowment Fund for Education) Scholarship for providing financial and non-financial assistance so that the authors can publish the results of research related to the farmers' perception toward agricultural land sustainability in peri-urban areas of Pekalongan City.

\section{REFERENCES}

Aulifia, A., Subejo, S., \& Harsoyo, H. (2016). Persepsi anggota grup Facebook "Komunitas Hidroponik Jogja (Hi-Jo)" terhadap pengembangan hidroponik. Agro Ekonomi, 27(2), 165-182. https://doi.org/10.22146/jae. 22691
BPS-Statistics of Pekalongan Municipality. (2018). Kota Pekalongan dalam angka. Kota Pekalongan, Jawa Tengah: Badan Pusat Statistik Kota Pekalongan. Retrieved from https://pekalongankota.bps.go.id/publication/ 2018/08/16/0a0b89aad205939169838531/kot a-pekalongan-dalam-angka-2018.html

Clay, D. C., Bro, A. S., Church, R. A., Ortega, D. L., \& Bizoza, A. R. (2018). Farmer incentives and value chain governance: Critical elements to sustainable growth in Rwanda's coffee sector. Journal of Rural Studies, 63(June), 200-213. https://doi.org/10.1016/j.jrurstud.20 18.06.007

Creemers, S., van Passel, S., Vigani, M., \& Vlahos, G. (2019). Relationship between farmers' perception of sustainability and future farming strategies: A commodity-level comparison. AIMS Agriculture and Food, 4(3), 613-642. https://doi.org/10.3934/agrfood.201 9.3.613

da Motta, R. S., \& Ortiz, R. A. (2018). Costs and perceptions conditioning willingness to accept payments for ecosystem services in a Brazilian Case. Ecological Economics, 147(May 2017), 333-342. https://doi.org/10.1016/j.ecolecon.2 018.01.032

Daulay, A. R., Eka Intan, K. P., Barus, B., \& Pramudya, N. B. (2016). Rice land conversion into plantation crop and challenges on sustainable land use system in the East Tanjung Jabung Regency. Procedia - Social and Behavioral Sciences, 227(2016), 174-180. https://doi.org/10.1016/j.sbspro.2016.06.059

Delsman, J. R., Hu-A-Ng, K. R. M., Vos, P. C., De Louw, P. G. B., Oude Essink, G. H. P., Stuyfzand, P. J., \& Bierkens, M. F. P. (2014). Paleo-modeling of coastal saltwater intrusion during the Holocene: An application to the Netherlands. Hydrology and Earth System Sciences, 18(10), 3891-3905. https://doi.org/ 10.5194/hess-18-3891-2014

Didomenica, B., \& Gordon, M. (2016). Food policy: Urban farming as a supplemental food source. Journal of Social Change, 8(1), 1-13. https://doi.org/10.5590/JOSC.2016.08.1.01

Duwit, B. S., Kumurur, V. A., \& Moniaga, I. L. (2015). Persepsi pedagang kaki lima terhadap area berjualan sepanjang jalan Pasar 
Pinasungkan Karombasan Manado. Sabua : Jurnal Lingkungan Binaan dan Arsitektur, 7(2), 419-427. Retrieved from https:// ejournal.unsrat.ac.id/index.php/SABUA/articl e/view/9586

Erfandi, D., \& Rachman, A. (2011). Identification of soil salinity due to seawater intrusion on rice field in the Northern Coast of Indramayu, West Java. Journal of Tropical Soils, 16(2), 115121. https://doi.org/10.5400/jts.2011.v16i2.11 $5-121$

Faridhavin, U., Witjaksono, R., \& Harsoyo, H. (2016). Persepsi pendamping terhadap pelaksanaan Program Upsus Pajale di Daerah Istimewa Yogyakarta. Agro Ekonomi, 27(2), 197-214. https://doi.org/10.22146/jae.22700

Fauzan, W. M., Soedwiwahjono, \& Miladan, N. (2017). Transformasi fisik wilayah peri urban di Kelurahan Madegondo Kecamatan Grogol Kabupaten Sukoharjo. Plano Madani : Jurnal Perencanaan Wilayah dan Kota, 6(2), 195204. Retrieved from http://journal.uinalauddin.ac.id/index.php/planomadani/article/ view/3467

Ghazanfar, S., Qi-wen, Z., Abdullah, M., Ahmad, Z., \& Lateef, M. (2015). Farmers' perception and awareness and factors affecting awareness of farmers regarding crop insurance as a risk coping mechanism evidence from Pakistan. Journal of Northeast Agricultural University, 22(1), 76-82. https://doi.org/10.1016/s10068104(15)30010-6

Gujarati, D. N. (2004). Basic econometrics (4th ed.). New York: The McGraw-Hill Companies.

Habtemariam, L. T., Gandorfer, M., Kassa, G. A., \& Heissenhuber, A. (2016). Factors influencing smallholder farmers' climate change perceptions: A study from farmers in Ethiopia. Environmental Management, 58(2), 343-358. https://doi.org/10.1007/s00267-0160708-0

Haryanto, L. I., Masyhuri, M., \& Irham. (2018). The policy analysis matrix in measuring competitiveness of maize farming system in marginal areas. Jurnal Agro Ekonomi, 29(2), 244-260. https://doi.org/10.22146/ae.35964

Hasanshahi, H., Iravani, H., Ameri, Z. D., \& Kalantari, K. (2015). Measure and comparison of economic, social and ecological sustainability of farming systems in the Marvdasht plain. Desert, 20(2), 231-239. Retrieved from http://search.ebscohost.com/ login.aspx ?direct=true $\& \mathrm{db}=\mathrm{a} 9 \mathrm{~h} \& \mathrm{AN}=118351$ 262\&lang=pt-br\&site $=$ ehost-live

Jamal, M., \& Mortez, S. S. (2014). The effect of urban agriculture in urban sustainable development and its techniques: A case study in Iran. International Journal of Agriculture and Forestry, 4(4), 275-285. https://doi.org/ 10.5923/j.ijaf.20140404.03

Jiang, L., \& Zhang, Y. (2016). Modeling urban expansion and agricultural land conversion in Henan Province, China: an integration of land use and socioeconomic data. Sustainability, 8(9), 920. https://doi.org/10.3390/su8090920

Kawung, A. V., Poluan, R., \& Rondonuwu, D. M. (2016). Persepsi dan sikap wisatawan terhadap objek wisata Bukit Kasih Kanonang di Kecamatan Kawangkoan Kabupaten Minahasa. Spasial, 3(1), 66-74. Retrieved from https://ejournal.unsrat.ac.id/index.php/sp asial/article/viewFile/11652/11244

Kiełbasa, B., Pietrzak, S., Ulén, B., Drangert, J. O., \& Tonderski, K. (2018). Sustainable agriculture: The study on farmers' perception and practices regarding nutrient management and limiting losses. Journal of Water and Land Development, 36(1), 67-75. https://doi.org/ 10.2478/jwld-2018-0007

Obaniyi, K. S., Akangbe, J., Matanmi, B. M., \& Adesiji, G. B. (2014). Factors motivating incentives of farmers in rice production training programmes (A case study of Olam/USAID/ADP/First Bank Programme). WebPub Journal of Agricultural Research, 2(5), 74-81. Retrieved from http://eprints.Imu. edu.ng/11/1/Obaniyi\%20et\%20al.pdf

Pradika, V., Masykuri, M., \& Supriyadi, S. (2019). Farmer awareness to the dangers of heavy metal Cadmium (Cd) pollution due to over-fertilization in Sragen Regency Central Java. Caraka Tani: Journal of Sustainable Agriculture, 34(1), 76-85. https://doi.org/10. 20961/carakatani.v34i1.27222

Prasada, I. Y., Dhamira, A., \& Nugroho, A. D. (2018). Supply response of paddy in East Java: Policy implications to increase rice 
production. AGRARIS: Journal of Agribusiness and Rural Development Research, 4(2), 129-138. https://doi.org/10.18 196/agr.4268

Purbiyanti, E., Muhammad, Y., \& Indri, J. (2017). Konversi lahan sawah di Indonesia dan pengaruhnya terhadap kebijakan Harga Pembelian Pemerintah (HPP) gabah/beras. Jurnal Manajemen \& Agribisnis, 14(3), 209217. https://doi.org/10.17358/jma.14.3.209

Ramzi, M., Hussain, M., Yusoff, N. H., \& Tukiman, I. (2017). Urban farming and its importance for environmental sustainability. Proceedings of Academics World 76th International Conference, Kuala Lumpur, Malaysia, 3rd August 2017, 11(August), 1316. https://doi.org/10.1088/1748-9326/11/12/ 120203

Rezai, G., Shamsudin, M. N., \& Mohamed, Z. (2016). Urban agriculture: A way forward to food and nutrition security in Malaysia. Procedia - Social and Behavioral Sciences, 216(October 2015), 39-45. https://doi.org/ 10.1016/j.sbspro.2015.12.006

Rondhi, M., \& Adi, A. H. (2018). The effects of land ownership on production, labor allocation, and rice farming efficiency. AGRARIS: Journal of Agribusiness and Rural Development Research, 4(2), 101-109. https:// doi.org/http://dx.doi.org/10.18196/agr.4265

Sari, K. D. R., \& Santoso, E. B. (2017). Analisis keterkaitan wilayah peri urban di Kabupaten Gresik dengan wilayah desa-kota di sekitarnya. Jurnal Teknik ITS, 6(2), 496-501. http://dx.doi.org/10.12962/j23373539.v6i2.24 971

Saturday, A. (2018). Restoration of degraded agricultural Land: A review. Journal of Environment and Health Science, 4(2), 44-51. https://doi.org/10.15436/2378-6841.18.1928

Septian, D., \& Anugrah, G. C. (2014). Perlindungan petani melalui konsep asuransi pada Gabungan Kelompok Tani Desa Argorejo, Kabupaten Bantul. Jurnal Penelitian Hukum, 1(2), 92-108. Retrieved from https://jurnal.ugm.ac.id/jph/article/view/ 19103

Sudirman, S. (2012). Valuasi ekonomi dampak konversi lahan pertanian di pinggiran Kota
Yogyakarta. AGRIKA: Jurnal Ilmu-ilmu Pertanian, 6(1), 103-125. Retrieved from http://publishing-widyagama.ac.id/ejournalv2/index.php/agrika/article/view/134

Suharyanto, Rinaldi, J., Arya, N. N., \& Mahaputra, K. (2017). Faktor-faktor yang mempengaruhi persepsi petani terhadap kebijakan perlindungan lahan pertanian pangan berkelanjutan di Provinsi Bali. Jurnal Pengkajian dan Pengembangan Teknologi Pertanian, 20(2), 111-124. http://dx.doi.org/ 10.21082/jpptp.v20n2.2017.p111-124

Sulewski, P., Kłoczko-Gajewska, A., \& Sroka, W. (2018). Relations between agri-environmental, economic and social dimensions of farms' sustainability. Sustainability, 10(12), 4629. https://doi.org/10.3390/su10124629

Sumarga, E., \& Hein, L. (2016). Benefits and costs of oil palm expansion in Central Kalimantan, Indonesia, under different policy scenarios. Regional Environmental Change, 16(4), 1011-1021. https://doi.org/10.1007/s10 113-015-0815-0

Ustaoglu, E., \& Williams, B. (2017). Determinants of urban expansion and agricultural land conversion in $25 \mathrm{EU}$ countries. Environmental Management, 60(4), 717-746. https://doi.org/10.1007/s00267-0170908-2

Virianita, R., Soedewo, T., Amanah, S., \& Fatchiya, A. (2019). Persepsi petani terhadap dukungan pemerintah dalam penerapan sistem pertanian berkelanjutan. Jurnal Ilmu Pertanian Indonesia, 24(2), 168-177. https:// doi.org/10.18343/jipi.24.2.168

Werner, A. D., Bakker, M., Post, V. E. A., Vandenbohede, A., Lu, C., Ataie-Ashtiani, B., Simmons, C. T., \& Barry, D. A. (2013). Seawater intrusion processes, investigation and management: Recent advances and future challenges. Advances in Water Resources, 51, 3-26. https://doi.org/10.1016/j.advwatres.201 2.03.004

Yasar, M., \& Siwar, C. (2016). Paddy Field Conversion in Malaysia: Issues and Challenges. Rona Teknik Pertanian, 9(2), 168-177. https://doi.org/10.17969/rtp.v9i2.56 53 